This is a pre-copyedited, author-produced PDF of an article accepted for publication in

Journal of Theological Studies following peer review. The definitive publisherauthenticated version in Volume 60, Number 2 (October 2009), pp. 467-489

is available online at http://jts.oxfordjournals.org/cgi/content/full/flp067

\title{
SCIENCE AND THEOLOGY IN \\ GREGORY OF NYSSA'S DE ANIMA ET RESURRECTIONE: \\ ASTRONOMY AND AUTOMATA. ${ }^{1}$
}

\begin{abstract}
This article examines two sections of Gregory of Nyssa's De anima et resurrectione which introduce scientific phenomena: from astronomy (eclipses; the phases of the moon) and physics (a water-device). Each passage is set in its intellectual context and possible sources are suggested. I argue that the water-device was part of an automaton, not a water-organ as previously argued. The primary importance of these passages, however, lies in their role in Gregory's dialogue as a whole: far from being merely illustrative or designed for rhetorical display, they drive the argument onwards. The first example establishes a general epistemological principle (knowledge requires the cooperation of reason and sense-experience) which is applied to the second example's argument for the existence of the soul. Gregory uses these examples to emphasise the importance of matter as part of God's good creation: this reinforces his later emphasis on the human body (especially its resurrection). Furthermore, the structure of each example mirrors a general movement in Gregory's dialogue from a rejection of materialism, to an affirmation of the soul, and then to an emphasis on the co-dependence of the immaterial and material in creation. They are thus both a microcosm of the treatise's main argument.
\end{abstract}

\footnotetext{
${ }^{1}$ This piece has been developed from a paper first presented at the XXXV Incontro di Studiosi dell'Antichità Cristiana, at the Augustinianum, Rome, (May, 2006).
} 


\section{Introduction}

This piece will take a close look at two short passages in Gregory of Nyssa's De anima et resurrectione: texts which deal with some basic questions in astronomy (eclipses and the phases of the moon) and with the construction of an object which makes a sound (which I will argue was part of an automaton). ${ }^{2}$ My interest in these passages derives not only from the description of the phenomena in question themselves, but also from the way in which they illustrate Gregory's literary style and theological-philosophical concerns.

As is well known, Gregory's De anima et resurrectione is a treatise on immortality and resurrection in dialogue form. The dramatic setting is the death-bed of Gregory's sister Macrina. Gregory arrives, seeking consolation for the death of their brother Basil, only to find her gravely ill too. Overcome with grief, he responds impatiently to his sister's suggestion that he moderate his tears: 'death then being naturally so terrible to us, how can it be easy for a survivor to obey this command to remain unmoved over friends departed?'3 Thenceforth, Macrina assumes the role of Gregory's teacher, countering his objections and leading him to a deeper understanding of the Christian hope. The dramatic setting in which one character faces death calmly and seeks to convert the fear and grief of the other(s) by the use of philosophy naturally invites the reader to compare Macrina with Socrates in the

\footnotetext{
2 This text has not yet been published in Brill's Gregorii Nysseni Opera. I have consulted the edition of Franz Oehler, Gregor's Bisshof's von Nyssa, Gespräch mit seiner Schwester Macrina, Über Seele und Auferstehung, Leipzig, 1858; in some places this offers some useful modifications of the text in volume 46 of Migne's Patrologia Graeca (=PG46). I have given references to both editions. The precise passages under discussion in this paper are: Oehler pp. 325:41 - 327: 2 and pp. 327:28 - 328:39; PG46: 32:11 33:35 and 36:25 - 40:4. The translation cited is that by W. Moore in the Nicene and Post-Nicene Fathers Series, second series, volume V (abbreviated here as NPNF V); for these passages see pp. 433-4 and pp. 435-6. I have also consulted and sometimes quote the translation by Catharine Roth St. Gregory of Nyssa, The soul and the resurrection (St. Vladimir's Seminary Press, Crestwood, N.Y., 1993) (see pp. 37-43).

${ }^{3}$ NPNF V, p. 430; PG46: 13:30 - 16:1; Oehler 320:6-8
} 
Platonic dialogue the Phaedo. ${ }^{4}$ Nevertheless, as other commentators have been quick to point out, Gregory's dialogue is by no means a simple repetition of the Phaedo in a Christian mode. For one thing, the Platonic resonances are complex, Macrina's characterisation owing something to the mysterious Diotima in the Symposium as well as to Socrates himself. ${ }^{5}$ Furthermore, Macrina's position in the dialogue is more vulnerable than that of Socrates in the Phaedo: Gregory the author cleverly uses the character Gregory to probe and question some of Macrina's theological and philosophical assumptions so that by the end of the dialogue both characters have modified their original starting-points. ${ }^{6}$ Finally, it seems impossible to identify the views of either Gregory or Macrina in the dialogue with those of the 'real' Gregory (although some have tried): the author seems deliberately to be obscuring his authorial voice. ${ }^{7}$

The purpose of this article, however, is to examine another aspect of Gregory's literary technique in the De anima et resurrectione: that is, his use of scientific analogies. Just as his use of the dialogue form creates a dynamic which drives the argument forward so, I will argue, the scientific examples - when read in the context

\footnotetext{
${ }^{4}$ On this, see e.g. Arnaldo Momigliano, 'The Life of Saint Macrina by Gregory of Nyssa' in Arnaldo Momigliano, On Pagans, Jews and Christians (Wesleyan University Press, Middletown, Connecticut, 1987), p. 208.

${ }^{5}$ See e.g. Elizabeth A. Clark, 'Holy women, holy words: early Christian women, social history and the 'linguistic turn', ', in Journal of Early Christian Studies, 6:3 (1998), e.g. p. 424; Catharine P. Roth, 'Platonic and Pauline elements in the ascent of the soul in Gregory of Nyssa's dialogue on the soul and resurrection' in Vigiliae Christianae 46 (1992) pp. 20-1; Burrus, Virginia, 'Begotten not made.' Conceiving Manhood in Late Antiquity (Stanford University Press, Stanford, California 2000), e.g. pp. 112-13.

${ }^{6}$ Rowan Williams, 'Macrina's Death-bed Revisited: Gregory of Nyssa on Mind and Passion', in Wickham, L. and Bammel, C. Christian Faith and Philosophy in Late Antiquity (= Supplements to Vigiliae Christianae 19) (E.J.Brill, Leiden, 1993), pp. 231-2.

${ }^{7}$ Clark, 'Holy women, holy words', p. 426; Roth, 'Platonic and Pauline elements', p. 21; Burrus, 'Begotten not Made', p. 113; p. 122; For an assessment of these readings of De anima et resurrectione see Morwenna Ludlow, Gregory of Nyssa, Ancient and (Post)modern (Oxford University Press, Oxford, 2007), pp. 206-19.
} 
of the theology of the treatise - can be understood not only as reflecting and reinforcing main themes of the work, but also as developing the course of its argument.

After the introduction which sets the scene, Gregory declares that he fears not only the dissolution of the body, but that of the soul also, and this confession leads Macrina first to ask him to refine his case and then to persuade him that his fears are false. So, Gregory presents his sister with a dilemma: either, if the soul resides in the elements of the body, it is identical with them and will be dissolved with them upon death; or, if the soul is not in the elements of the body, its location is unknown. (The implicit conclusion is that it is nowhere.) Macrina 'groans quietly' at the way in which her brother grasps at 'Stoic or Epicurean' objections and launches an attack on a materialist view of the universe which particularly focuses on the errors of Epicurus. ${ }^{8}$ His fundamental error, she argues, was to fail to perceive anything beyond the material: he ignored the order of the universe and was thus blind to the one who created it. Epicurus and those like him, Macrina asserts, failed to understand that 'a Divine power, working with skill and method, is manifesting itself in this actual world, and, penetrat[es] each portion', ${ }^{9}$ and, furthermore, that humanity is a microcosm of the world, ${ }^{10}$ reflecting the composition of the whole universe not just in the combination of different elements making up the body, but also in its combination of a material body with immaterial soul. That this echoes, but is not exactly parallel to, the divine power working in the universe will become evident in the rest of the treatise. Macrina then proceeds to argue that one needs to reason through one's sensed perceptions of the world and of human nature in order fully to understand them.

\footnotetext{
${ }^{8}$ PG46: 21:12 - 24:35; Oehler 322:9-323:12

${ }^{9}$ PG46: 28:5-7; Oehler 324:7-8; tr. NPNF V p. 433

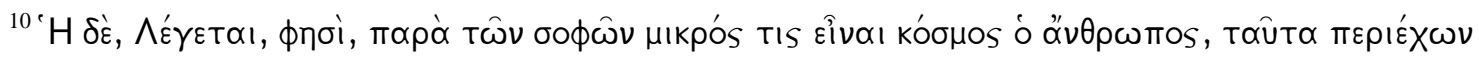

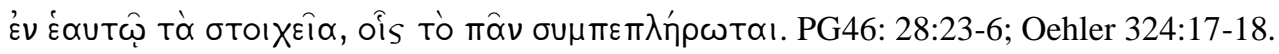




\section{Astronomy: the size of the sun and the phases of the moon [PG 46: 32-3; Oehler 325:11 - 327:2]}

In this passage Macrina develops her argument that sense perception and reason together are necessary for a correct understanding of the world. She has just illustrated this with the example of a doctor who uses his senses of touch, sight, hearing and even smell to diagnose an illness, and concludes - supposedly quoting words from 'one of those educated in pagan things" ${ }^{\text {"1 }}$ - that 'it is the mind which sees and the mind which hears'. ${ }^{12}$ In her translation of De anima et resurrectione, Catharine Roth suggests that Gregory is alluding to Epicharmus. ${ }^{13}$ This may indeed be the case, but Macrina's words are also surely a more general reference to philosophical debates about the epistemological value of the senses. This debate goes back to some of the Platonic dialogues, in particular the Phaedo and the Republic. For example, in the Phaedo Socrates asks:

'Now, how about the acquirement of pure knowledge? Is the body a hindrance or not, if it is made to share in the search for wisdom? What I mean is this: Have the sight and hearing of men any truth in them, or is it true, as the poets are always telling us, that we neither hear nor see any thing accurately? And yet if these two physical senses are not accurate or exact, the rest are not likely to be, for they are inferior to these. Do you not think so? ${ }^{, 14}$

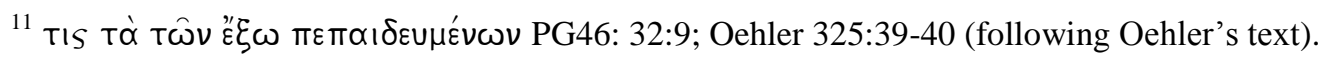

${ }^{12}$ PG46: 32:10-11; Oehler 325:39-41.

${ }^{13}$ Roth, p. 38 n.2, cites Epicharmus, fr.249, quoted by Theodoret in De Fide 1: 'The mind sees and the mind hears; the rest is deaf and blind'.

${ }^{14}$ Phaedo 65a-b, tr. H. N. Fowler in Plato, Euthyphro, Apology, Crito, Phaedo, Phaedrus, Loeb Classical Library (Cambridge, MA, Harvard University Press; London, William Heinemann, 1953); c.f. 65e-66a '[Socrates:] "Would not that man do this most perfectly who approaches each thing, so far as possible, with the reason alone, not introducing sight into his reasoning nor dragging in any of the other senses along with his thinking, but who employs pure, absolute reason in his attempt to search out the pure, absolute essence of things, and who removes himself, so far as possible, from eyes and ears, and, in a word, from his whole
} 
Socrates cites as a particular cause of disappointment Anaxagoras' explanation of celestial phenomena. ${ }^{15}$ In the Republic, famously, Socrates is portrayed as being interested in astronomy not insofar as it has a practical use, but only insofar as one can rise above the perception of material phenomena towards an immaterial truth. $\mathrm{He}$ criticises astronomers for being too fixated with the phenomena as such. ${ }^{16}$ Many later writers tempered this position, taking a slightly more positive view of the role of the senses, but also of astronomy as a discipline in itself. Macrina's words are, for example, strikingly reminiscent of a passage from Philo's De congressu eruditionis gratia:

The eyes see, but the mind through the eyes sees further than the eyes. The ears hear, but the mind through the ears hears better than the ears. The nostrils smell, but the soul through the nose smells more vividly than the nose, and while the other senses apprehend the objects proper to them, the understanding apprehends with more purity and clarity. For we may say quite properly that the mind is the eye's eye, the hearing's hearing and the purified sense of each of the senses; it uses them as ushers in its tribunal, but itself passes judgment on the natures of the objects presented, giving its assent to some and refusing it to others. ${ }^{17}$

Nevertheless, in his treatise, Philo distinguishes 'arts' (or 'intermediate arts') - which proceed by 'simple observations' - from 'science', which advances 'with greater accuracy and with exceedingly careful investigation'. Astronomy and geometry, grammar, music, rhetoric and dialectic are arts, each of which observes a particular

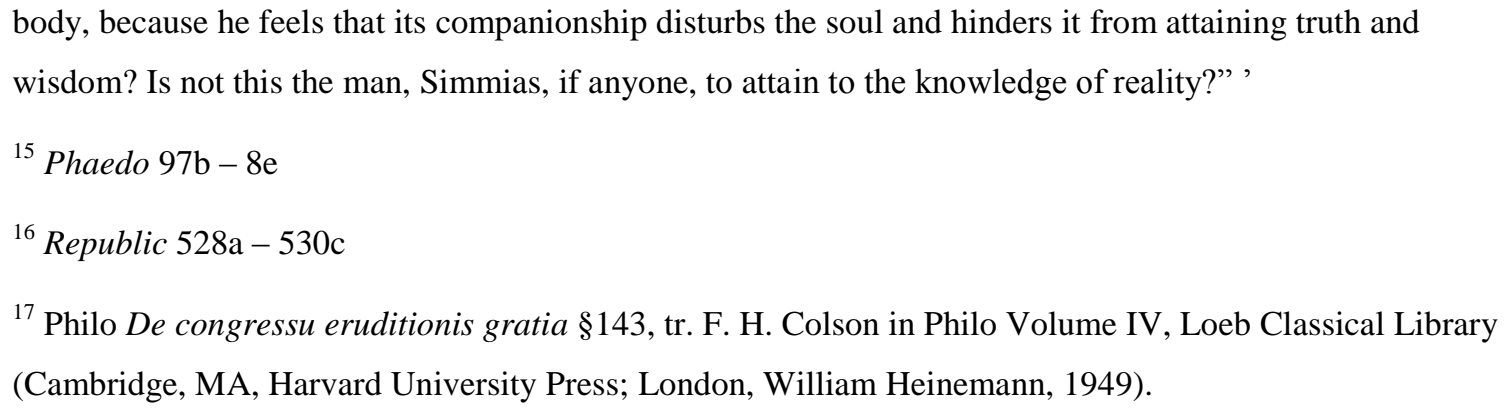


(that is, partial) aspect of the universe and each of which is handmaid to philosophy which has as its subject-matter 'the whole essence, both visible and invisible, of existing things'. ${ }^{18}$ The supreme science - strictly the only true science - is philosophy.

By Gregory's day, then, astronomy had become well established as one of the classic examples used in the examination of epistemology, the fact that the movements of the heavenly phenomena were notoriously difficult both to observe and to describe with accuracy. Gregory's dialogue fits well into this background, for Macrina is portrayed as illustrating her point about sense and reason with two examples from basic astronomy. However, as we shall see, astronomy is valued very highly in De anima et resurrectione: Macrina's argument implies that when done well it proceeds 'with... accuracy and with exceedingly careful investigation', to use Philo's words. Perhaps for Gregory, then, astronomy can in itself be a science. For Plato (in some dialogues such as the Phaedo and the Republic) the senses were a hindrance to true knowledge, and astronomy was only good insofar as it led the mind away from the senses. Philo gives a more positive role to the senses, provided they are judged by the mind, but firmly situates the senses, together with disciplines based on sense-perception (like astronomy) in an inferior position as philosophy's handmaids. In De anima et resurrectione Gregory seems to be moderating the original Platonic position still further, by being even more positively disposed towards the senses than Philo and - as we shall see - by appearing to regard disciplines like astronomy as important and interesting in themselves.

Macrina introduces her examples from astronomy as if she were reminding Gregory what he had been taught by his teacher (indeed, it is more than likely that Gregory's education involved some astronomy). In each case, she reminds Gregory that things are often not what they first appear to be, but that one can understand the truth by reasoning through one's perception of appearances. Thus, in the case of the sun, it is not merely as big as the disk in the sky, as it seems to most people, but it is

\footnotetext{
18 ibid. $\$ 144$
} 
many times bigger. This we can tell by using our reason, working to a conclusion

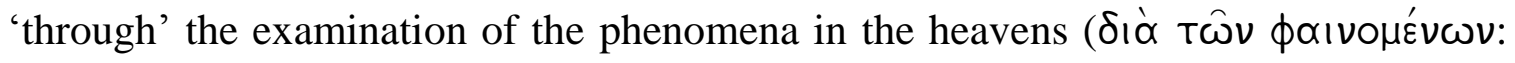
$326: 6$, c.f. $326: 8)$ - that is, what kind of movement the sun has, its distance from the earth and other planets measured in terms of space and time, and the causes of eclipses. Similarly, with the moon: by looking at the waxing and the waning of the

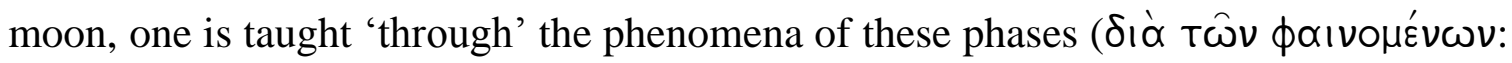
326:40) about the nature of the moon itself, in particular that of all the planets it has the orbit closest to the earth and that it has no light of its own but shines with light reflected from the sun. Macrina then proceeds to give a more detailed explanation of the phases of the moon.

Although the argument concerning the moon is much longer than that about the sun, the basic structure of the two is very similar:

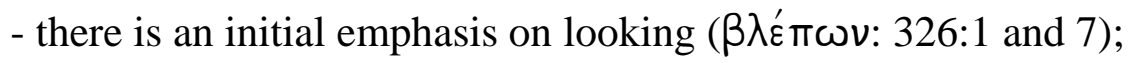

- Macrina then contrasts correct looking with the perceptions of most people

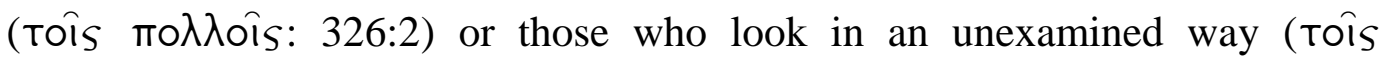

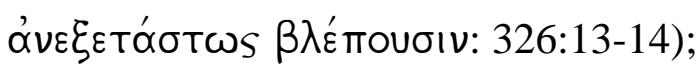

- in both cases there is a tension between saying, on the one hand, that mere appearances/mere phenomena are not enough and, on the other hand, that reason uses appearances to achieve true understanding: hence the stress on

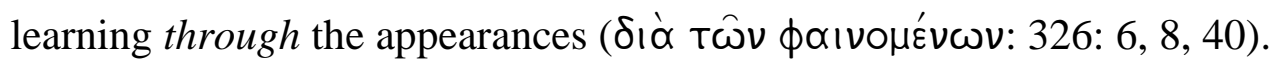

With regard to this last point, Gregory's Greek relies on the ambiguity of the Greek

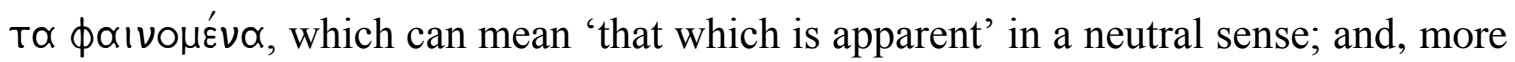
negatively, 'that which appears to be the case [but is not]'. These meanings are in

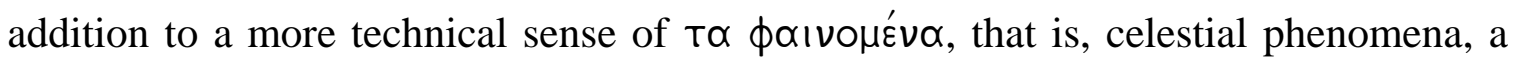
meaning found, for example, in the title of the work of Eudoxus, which famously became the basis of a didactic poem with the same name by Aratus. In the first example, Macrina's argument moves from a description of the way in which the sun appears to be a disk in the sky (but is not) to a discussion of much more complex

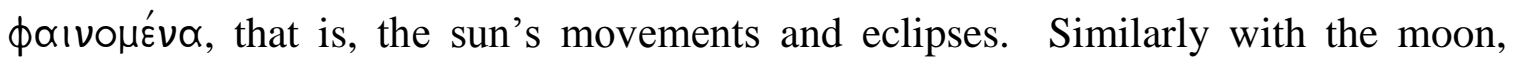
Macrina notes that it appears to shine with its own light, and that it appears to change 


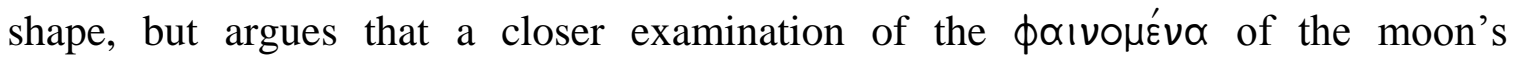
movements shows otherwise. Through these examples, Macrina teaches Gregory that one cannot achieve deep understanding by looking at the phenomena of the heavens in an unreasoning way. Rather, there is 'something looking through the sense of sight which can use the things which come to perception as guides to penetrate through the appearances to that which is not [a mere] appearance'. ${ }^{19}$ She compares this process to the use of geometrical diagrams which point to, or prompt the mind to conceive of, concepts which transcend the marks on the page. But - unlike Plato in the Republic this is a comparison. Macrina does not reduce astronomy to the search for immaterial truths: it is the search for a truth about the world.

Besides the use of the ambiguity in the term $\tau \propto$ фoı this passage some playful variation on the theme of teachers and teaching. At the beginning of her speech Macrina is herself introduced as Gregory's teacher - $\dot{\eta}$ $\delta ı \delta \propto \alpha \sigma k \alpha \lambda \circ s^{20}$ The section on astronomy begins with Macrina reminding Gregory

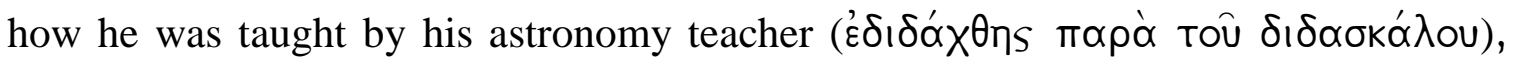
and closes with Macrina's remark that in fact Gregory’s sight is his teacher (opộs

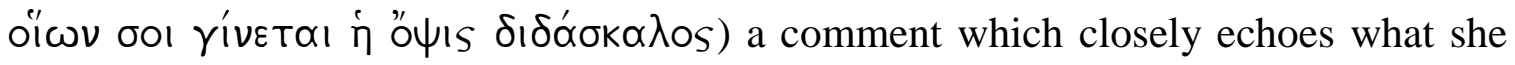

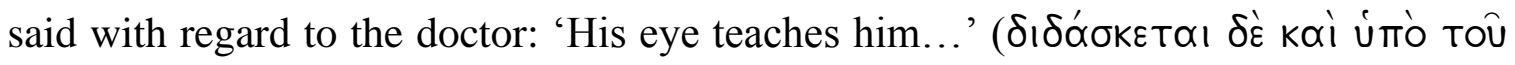
ö $\theta \propto \lambda \mu \circ \hat{)}) .^{21}$

This preoccupation with teaching and with the contrast of how things appear and how they really are, should alert us, I think to the fact that Gregory is not interested in the astronomical phenomena in themselves, but is also using them for his own philosophical and theological ends. This conclusion is perhaps not very

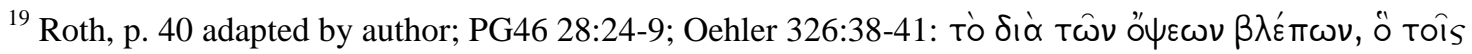

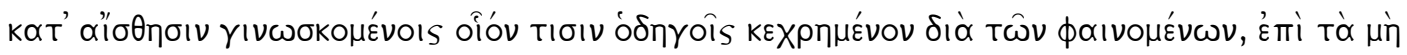
$\beta \lambda \varepsilon \pi \dot{\mu}_{\mu \varepsilon v \propto} \delta ı \propto \delta \dot{v \varepsilon \tau \propto ı . ~}$

${ }^{20}$ PG46 29:22; Oehler 325:11

${ }^{21}$ PG46 32:13; Oehler 326:1-2; PG46: 33:24; Oehler 326:37; PG46: 29:39; Oehler, 325: $23-4$ (Roth, p. $38)$.
} 
surprising, but I emphasise it because both here and in many other places Gregory describes phenomena in the natural world in a lot of detail. Indeed, his detailed accounts of such things as the phases of the moon, have been used by some writers to argue for his authorship of 'Letter 38', which was traditionally attributed to Basil and in which the author indulges in a long explanation of the phenomenon of rainbows. ${ }^{22}$ Such detail, such a tendency to get carried away with the details of the description is, it is argued, much more typical of Gregory's style than Basil's. This is, I think, the case. But the relatively detailed nature of such descriptions should not lure us into thinking that Gregory's interest in science is anything more than that of a relative amateur (a well-educated gentleman), nor into thinking that he is describing cuttingedge ancient science.

A closer examination of the case at hand should make this clear. Gregory is claiming that the correct observation of the phases of the moon should reveal that the moon has the orbit nearest the earth and that the moon is lit by the sun which, one can deduce from Gregory's remarks, has the next closest orbit to the earth. (Gregory, is of course, working with the model of a geocentric universe). But neither of these claims was new. The Presocratic writer Anaxagoras is credited with being the first to discover the causes of the moon's phases and eclipses and he also claimed that the moon got its light from sun. ${ }^{23}$ This latter point is reported in Plato's Cratylus, which remarks on Anaxagoras' 'recent doctrine' that the moon reflected the sun's light. ${ }^{24}$ Anaxagoras' views are reflected in Plato's own cosmology elsewhere in his writings:

\footnotetext{
${ }^{22}$ Thus see P. Fedwick 'A commentary of Gregory of Nyssa or the $38^{\text {th }}$ Letter of Basil of Caesarea', in Orientalia Christiana Periodica 44 (1978), 31-51. The evidence is usefully reviewed by Anna Silvas Gregory of Nyssa: The Letters Supplements to Vigiliae Christianae 83 (Brill, Leiden, 2007), p. 247-9.

${ }^{23}$ See D. R. Dicks Early Greek Astronomy to Aristotle (Thames and Hudson, London, 1970), p. 57-9, citing Anaxagoras Frg. B18 (the sun gives the moon its light) and Hippolytus Refutatio omnium haeresium i.8.7-9 (on the moon, its position and eclipses); see also James Evans, The History and Practice of Ancient Astronomy, (OUP, NY/Oxford, 1998), p. 46.

${ }^{24}$ Plato, Cratylus 409a, tr. Harold N. Fowler in Plato, Cratylus, Theaetetus, Sophist, Statesman, Loeb Classical Library (Cambridge, MA, Harvard University Press; London, William Heinemann, 1921).
} 
the myth of the cave in the Republic implies that the moon reflects light from the sun; ${ }^{25}$ the myth of Er in book X states this explicitly. ${ }^{26}$

After Plato, Greek astronomical theory sought to explain the motion and positions of the moon, sun and planets with more precision. Eudoxus (c. 390 - c. 340) was probably the first Greek astronomer to use systematic mathematical calculations to explain the irregularities in the movements of the moon and the sun. ${ }^{27}$ Hipparchus (c. $190 \mathrm{BC}$ - ca. 120 BC) refined this work to yield 'the first quantitatively adequate account' of these irregularities. ${ }^{28}$ Both seem to have calculated the eclipses of the moon using a combination of observation and

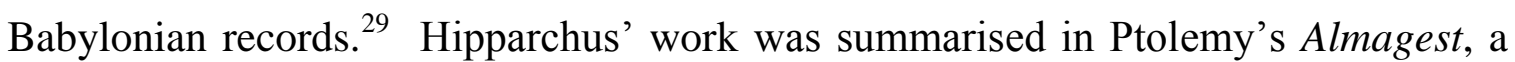
massive and ground-breaking second century AD astronomical work, which recorded, analysed and corrected previous astronomers' findings. Even if Gregory did not have direct access to it, he would surely have known of its existence. Nonetheless, Ptolemy's astronomical writing is far more complex than the simple notions put forward by Gregory in the De anima et resurrectione. In the terminology used by writers such as Dicks and Kuhn, the work of Eudoxus, Hipparchus and Ptolemy was quantitative (using mathematics to establish its conclusions), whereas Gregory's writing on astronomy was qualitative, seeking merely an effective description of the phenomenon, not a mathematical analysis which would, for example, enable one to predict the timing of future occurrences. In this Gregory's writing is perhaps more

\footnotetext{
${ }^{25}$ Plato, Republic, $516 \mathrm{~b}$

${ }^{26}$ Plato, Republic, 616e: 'that [body] of the eighth [orbit - i.e. that nearest the earth] took its colour from the seventh which shone upon it' tr. Paul Shorey in Plato, Republic, Loeb Classical Library (Cambridge, MA, Harvard University Press; London, William Heinemann, 1956).

${ }^{27}$ Dicks, Early Greek Astronomy to Aristotle, p. 153

${ }^{28}$ Thomas S. Kuhn, The Copernican Revolution (Harvard University Press, Cambridge MA,1957), p. 72.

${ }^{29}$ Michael Hoskin (ed.) Cambridge Illustrated History of Astronomy (Cambridge University Press, Cambridge, 1997), p. 36ff; A. Pannekoek A History of Astronomy (George Allen and Unwin, London, 1961), p. 128-9. On the (contested) influence of Babylonian on Greek astronomy, particularly Eudoxus' earlier use of Babylonian calculations, see Dicks, Early Greek Astronomy to Aristotle, pp. 165-75.
} 
similar to Aratus' hugely popular, but non-mathematical, third century BC poem based on Eudoxus' work.

Other arguments which are similar to Gregory's descriptions of the moon can be found in Plutarch dialogue On the Face which appears in the Moon (De facie) and this work offers a clue, I think, to Gregory's own choice of example. In De facie, before the apparent shadows on the moon's surface can be explained, the question of whether the moon shines with its own light or that of the sun has to be settled. ${ }^{30}$ It thus becomes apparent that despite the work of writers like Anaxagoras centuries before, the question of the sun's light, far from being settled, had become a bone of contention not so much between astronomers as between the various philosophical schools. Whilst the Academicians followed Plato in asserting that the moon was composed of earthy matter and shone with light reflected from the sun, the Peripatetic school asserted that the moon (like all planets) was made of the 'fifth substance' ether, and the Stoics claimed that the moon shone with its own light. ${ }^{31}$ Without going into the details of the dialogue, it is clear that De facie reveals Macrina's description of the moon as being part and parcel of later Platonism's standard assertions about cosmology. In sum, this - together with the aforementioned emphasis on teaching, perception and appearances - firmly situates Gregory's comments on the moon in a philosophical rather than in a scientific context.

Of course, in this period there was not always a clear distinction between 'natural science' and 'natural philosophy': what I am claiming, however, is that Gregory's comments relate to fundamental propositions about the make-up of the universe - to cosmology - rather than to the complex arithmetical or geometrical models for understanding particular phenomena or to anything other than the most basic of observations. Gregory gives an air of authenticity to his dialogue by mentioning diagrams at the end of our section, but whether he could describe these in any more detail is, I think, rather doubtful. His technique here can perhaps be

\footnotetext{
${ }^{30}$ Plutarch De facie $921 \mathrm{ff}$

${ }^{31}$ See e.g. De facie $921 \mathrm{E}-923 \mathrm{~A}$
} 
compared to his procedure in his Against Fate: there, in response to an accusation that he knows nothing of 'celestial things', Gregory reveals that he knows enough to give an account of the movement of the stars which provides a philosophical ground for dismissing the concept of fate. ${ }^{32}$

In sum, the more weighty lesson to be drawn from Macrina's use of astronomy concerns not cosmology, but epistemology. The reader is taught that appearances are deceptive and that they need to be interpreted using reason: it is the mind which sees. However, the author's emphasis that good understanding of the world depends on reasoning through sense perception, his use of the double meaning of the term phainomena and the repetition of the idea that one's eyes (or ears or nose) are ultimately good teachers all draw the reader to a complementary idea: that the immaterial intellect works in harmony with and through the material body. To put it another way: while the 'apparent' focus of the example is on the immaterial (reason), there is an equally important, but less obvious, emphasis on the material (the senses). Turning to our second example, we will see that its scientific model functions in a similar way.

\section{The vacuum and fluid mechanics: the creation of a device which makes a pipe sound when water is poured into it. [PG46: 36-40; Oehler 327:28 - 328:39]}

My second example is complicated by the fact it is far from clear what object, or objects, Macrina is describing. I will begin with an attempt to identify this object by focusing carefully on the lines which introduce and follow its description. I will then draw some conclusions about how Gregory uses the example, particularly with regard to its epistemological significance.

Following Macrina's masterful demonstration of the nature of perception, Gregory tentatively suggests that although the mind may appear to work though the senses, in fact it might be the case that there is some dynamic power in the material

\footnotetext{
${ }^{32}$ Gregory of Nyssa, Contra Fatum GNO vol.III.2, 34:15-16; 35:21-36:13.
} 
senses, not a rational soul which transcends them. He argues that people are not so silly as to think that there is an immaterial soul in objects made 'by machine-makers'

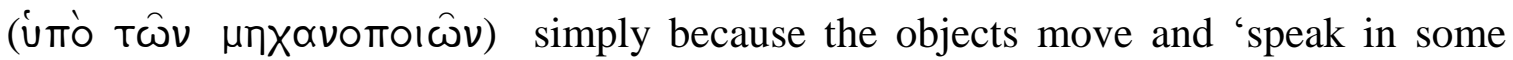

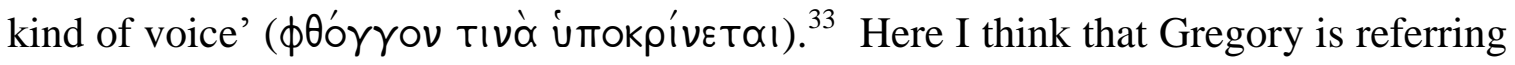
to the sort of automata famously described by Hero of Alexandria: models of humans, animals or gods, which were made to move by various means, including the flow of water and the use of heat and steam. ${ }^{34}$ Gregory might also be referring to contraptions which were used on the theatre stage and which moved and made sounds. $^{35}$

Macrina's reply can be helpfully divided into three parts. She first asserts that actually such automata prove her point, since although they do not have souls themselves, they could not exist without human designers with rational souls who observe the characteristics of water and air, and then create and design machines which use those forces in their operation. ${ }^{36}$ Secondly, she expounds this thought by describing one particular object which works on the principle that there is no such thing as a vacuum in an apparently empty jar. I will discuss the identity of this mystery object below. ${ }^{37}$ Thirdly, after describing this object, Macrina concludes that

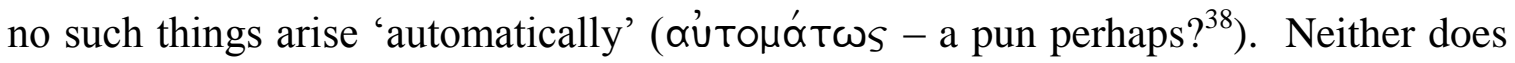

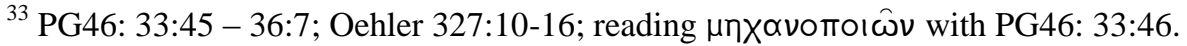

34 'Automaton' is to be understood in a minimal sense here, as a model with one or two moving or sounding parts - not anachronistically as a fully-moving or life-like representation of a human or animal form.

${ }^{35} \mu \eta \chi \propto$ Хvoтroíos was sometimes used of those who made contraptions for the stage (see e.g. Aristophanes Peace 174); the verb úmoкpívouaı could be used to mean 'to play a part on stage', 'to interpret' or 'represent' a character in a drama (see: Liddell and Scott Greek-English Lexikon $9^{\text {th }}$ edition).

${ }^{36}$ PG46: 36:25-35; Oehler 327:28-35

${ }^{37}$ PG46: 36:36 - 37:27; Oehler 327:36-328:19

${ }^{38}$ Hero uses the word aưtó $\mu$ arov for an automaton-like device in Pneumatics: Greek text ed. Wilhelm Schmidt, Herons von Alexandria Druckwerke und Automatentheater (Teubner, Leipzig, 1976), i:10:3; i:42:59.
} 
the object she has described occur automatically, nor do bronze statues form themselves, nor does air resonate by itself, nor does water flow uphill of its own accord. ${ }^{39}$ Although these phenomena are strung together at apparent random, I think that it is plausible, given Gregory's probable reference to an automaton above, that in these concluding remarks Macrina is meaning to indicate several aspects of such an automaton: the bronze statue, the pipes within it which are specially constructed to imitate a voice, the water flowing into it to make the statue move and/or the pipes sound.

Given this context, it seems to me to be very likely that the mystery object which Macrina describes is a simplified example of the sort of mechanism which causes sound to come from such an automaton. In other words, it is not a waterorgan, as some editions claim. ${ }^{40}$ This is supported by a closer look at Gregory's text. Macrina argues that the designers of such objects noticed that moving air is necessary for the production of sound. ${ }^{41}$ They then addressed the question of how to make air move within a machine $\left(\tau \hat{\omega} \mu \eta \chi \alpha \nu \eta^{\prime} \mu \alpha \tau 1\right) .{ }^{42}$ This question was solved by reflection on the principle that there is no such thing as a container being truly empty (K£vòv). ${ }^{43}$ This principle, Macrina claims, was derived from the observation that a jar when placed in water, does not fill immediately and that, in particular, the air leaving it and water entering create a 'fight' $(\mu \alpha \times\rceil \eta)$ in the neck of the jar causing the water to

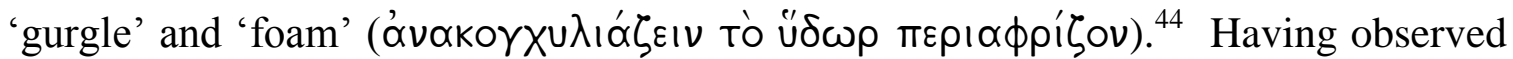

\footnotetext{
${ }^{39}$ PG46: 37:27 - 40:6; Oehler 328:19-39

${ }^{40}$ See Roth's translation of The soul and the resurrection, p. 42, n.4; W. Moore's translation NPNF V, p. 435, n. 2

${ }^{41}$ PG46: 36:36-7; Oehler 327:36-37

${ }^{42}$ PG46: 36:38; Oehler 327:37; see also PG46: 37:14; Oehler 328:12

${ }^{43}$ PG46: 36:39 etc.; Oehler 327:39 etc.

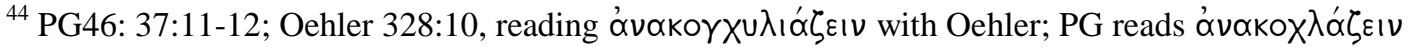

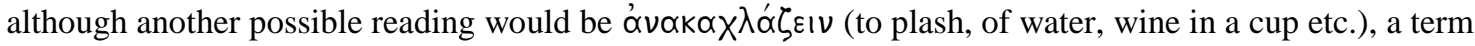
which is used in Hero Pneumatics i:15:14.
} 
this phenomenon, Macrina claims, someone then made a receptacle (Tò koî̀ov)

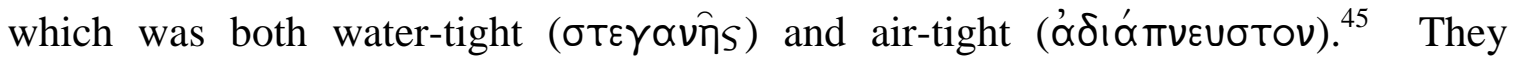

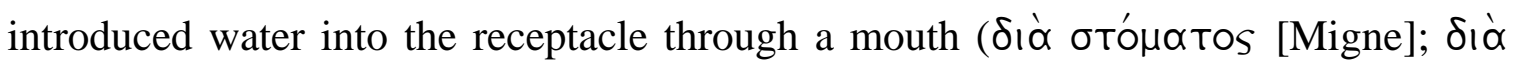
бтонíu [Oehler]), measuring it according to their need; there was also a pipe (Tòv

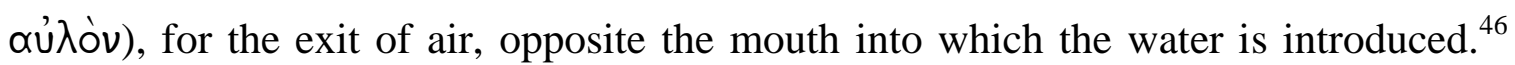
The pipe was constructed in such a way that when air ran through it, it made a sound. Macrina's description concludes by saying that when water is poured through the mouth 'the air, compressed by the water more forcefully, becomes a breath and when it encounters the construction of the pipe it makes a call'. ${ }^{4}$

I think that this is a simplified description of a basic mechanism such as those described by Hero of Alexandria in his work on pneumatics. For example, Hero describes a water-tight, air-tight box with two pipes in the top surface, but at opposite ends. ${ }^{48}$ One, like a funnel directs water into the box via a pipe which is fitted in such a way as to make the back-flow of air up the pipe virtually impossible. At the other end, a pipe leads to a small model of a bird or such like. When a quantity of water is poured into the box, the air inside the box is compressed causing a breath to pass out of the pipe, making it sound, imitating the voice of a bird. ${ }^{49}$ Later in the Pneumatics, Hero describes how such a device could be adapted to various more complex

\footnotetext{
${ }^{45}$ PG46: 37:15-17; Oehler 328:13-14

${ }^{46}$ PG46: 37:17-20; Oehler: 328:14-6

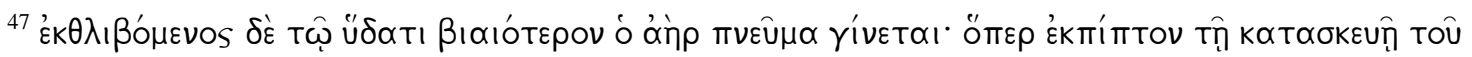

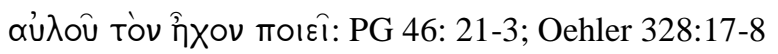

${ }^{48}$ Hero of Alexandria Pneumatics, tr. Bennet Woodcroft, facsimile edition ed. Marie Hall (Macdonald, London,1971), for the simplest device, see section 14 ('A bird made to whistle by flowing water'); Schmidt

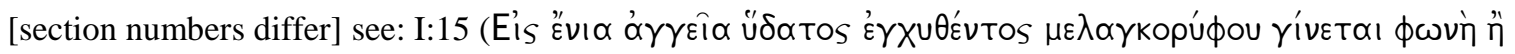

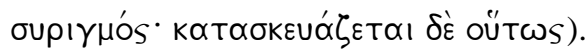

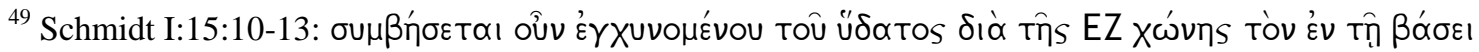

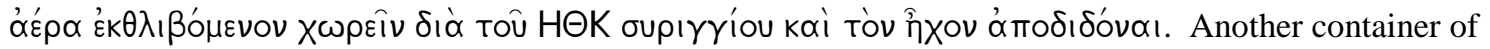
water can be used where the air leaves the pipe, which alters the sound to make the warble characteristic of a particular breed of bird.
} 
purposes. $^{50}$ Although he only discusses the imitation of birdsong and trumpets playing, it is not improbable that the same principle was applied to other automata, even those in human form. ${ }^{51}$

Gregory's description is clearly not that of a water-organ (hydraulikos organos or sometimes hydraulis). For one thing, these were extremely complex pieces of machinery: Gregory's example has neither the multiple pipes nor the keys which were a feature of such machines, allowing the player to create a melody. The machine Macrina describes seems able to play only one note and the note is produced directly with the influx of water, without the intervening manipulation of a key. More importantly, ancient water-organs lacked the essential feature which Macrina appears to describe: that is, the influx of water and the out-flow of air. The water-organ described by Hero of Alexandria created sound by the in-flow of air and out-flow of air. The movement of air was created by someone pumping a large lever; the machine was named a water-organ because it contained a certain amount of water which acted to maintain a constant air-pressure, so that a sequence of notes could be sounded without interruption regardless of the position of the lever pumping the air. Hero also describes another alternative organ which used wind-power to maintain the flow of air. ${ }^{52}$ In many accounts of ancient music, Ctesibius is credited with the

\footnotetext{
${ }^{50}$ Woodcroft, sections 43 ('Notes from a bird produced at intervals by an intermittent stream of water') and 44 ('Notes produced from several birds in succession, by a stream of water'). Schmidt: II:4 ('Ek

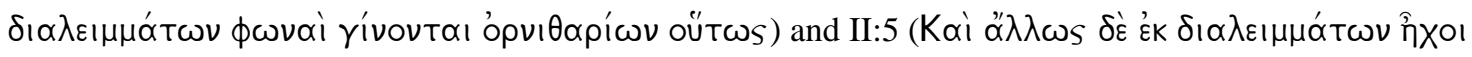

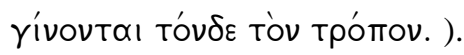

${ }^{51}$ A similar, but not identical, method using water to increase air-pressure is used to make an automaton sound a trumpet: Woodcroft §49; Schmidt ii:10.

${ }^{52}$ Hero Pneumatics, Woodcroft $§ 76$ 'An Altar organ blown by manual labour' (see especially the last paragraph which explains the mechanism for drawing into the machine 'air from without', and the reason for filling one of the containers with water - that is, to maintain a steady pressure: p. 107); Schmidt,

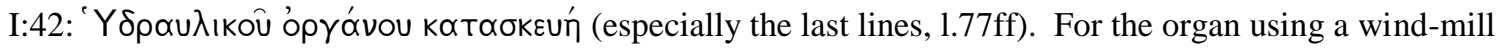
(rather than an air pump operated by a lever) but which does not contain water, see Woodcroft $§ 77$,

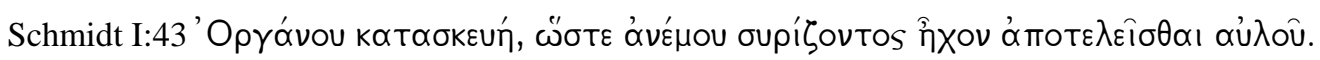


invention of the water-organ: his device too (at least as it is described by Vitruvius) depended on water for the maintenance of steady air-pressure but also required the introduction of air using bellows or similar. ${ }^{53}$

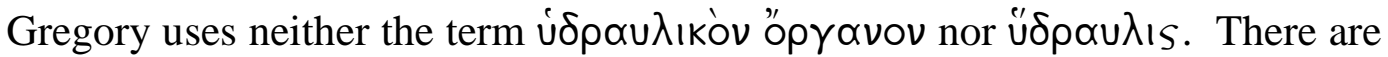
some similarities of expression between the descriptions of the water-mechanism in his and Hero's text, although not so striking as to give one confidence that he is alluding to Hero's very account. ${ }^{54}$ Macrina's description of the water-device is full of unusual words, which Gregory appears to have borrowed from all over the place, or in at least one case - invented himself. ${ }^{55}$ The passage is clearly intended to

\footnotetext{
${ }^{53}$ Vitruvius, The Ten Books of Architecture Book X.8 (Vitruvius does not explicitly say that he is describing Ctesibius' own invention, but that is the clear implication of the concluding sentence of X.7); see also Philo of Byzantium Belopoeica H. Diels and E. Schramm, Philons Belopoiika [Abhandlungen der
} preussischen Akademie der Wissenschaften, Philosoph.-hist. Kl. 16. Berlin: Reimer, 1919], following the pages numbers of the Thevenot edition 77:42ff (accessed through the on-line Thesaurus Linguae Graecae http://www.tlg.uci.edu/ ). It has to be admitted, that there is a great deal of uncertainty about the construction and nature of very early musical organs, and even more uncertainty about the terminology. Although some popular sources claim that early water-organs were powered by the influx of water this appears not to be correct from an examination of the sources. See also, Jeremy Montagu 'Hydraulis' in Alison Latham (ed.) The Oxford Companion to Music (Oxford University Press, Oxford, 2002; accessed via: Oxford Reference Online. Oxford University Press http://www.oxfordreference.com; accessed on 25 July 2008): '[Hydraulis] The earliest form of organ, its invention attributed to Ctesibius in Alexandria about $300 \mathrm{BC}$.... A pump on each side provided the air, the pressure being stabilized by a tank of water, hence the name (Gk. hydor, 'water', aulos, 'pipe')'.

${ }^{54}$ Compare footnotes 44 and 46 above; also see note 41 .

${ }^{55}$ As has been noted by previous commentators, Gregory and the other Cappadocians are fond of using unusual words - particularly those formed by the piling up of several prefixes. For example, the passage

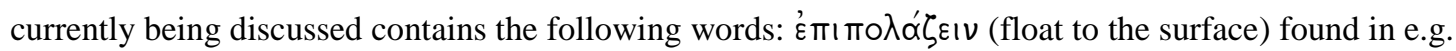

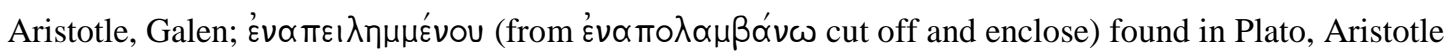

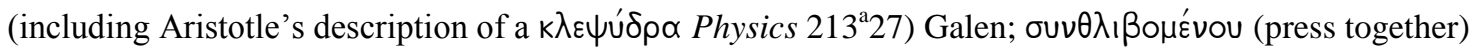
found in Aristotle, Plotinus, Plutarch, LXX, Philo, Galen, Oribasius - but by far the greatest number of

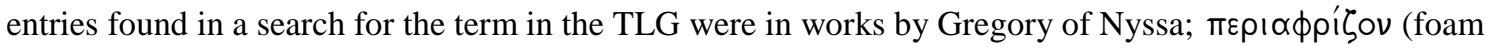

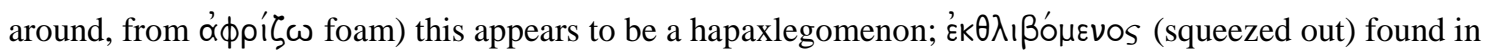
e.g. Aristotle, Galen (many times in De usu pulsuum); many later medical writers, including Oribasius; 
demonstrate Gregory's ability to produce verbal fireworks, but as a result it is not possible to trace the description of the water-device back to one particular source with certainty using verbal echoes alone.

More convincing is an argument from the context, particularly the fact that the dialogue seems to be referring to automata before and after the description of the object, as I have already explained above. Furthermore, the order in which Macrina describes the creative process is in some ways similar to the structure of the Proem to Hero's work on pneumatics. Hero first deals with the problem of the vacuum ( $\pi \varepsilon \rho i$ KघVOUิ): 'vessels which seem to most men to be empty are not empty, as they suppose, but full of air'. ${ }^{56}$ He then proves this by giving an account of simple experiments with pots and water. These experiments are not identical with Macrina's example of the water-jar, but their explication does contain the vivid phrase 'the air when set in motion becomes wind', which closely echoes the conclusion of Macrina's description of the water-mechanism. ${ }^{57}$ Hero's work then proceeds through descriptions of basic water-mechanisms, such as the one discussed here, and from them to more and more complex automata. This is similar to the sequence taken by Macrina: discussion of the vacuum, example of a simple mechanism, conclusion with reference to the component parts of a larger mechanism. The major difference is that Macrina announces her interest in automata right from the start.

I think, then, it is very likely that in De anima et resurrectione Macrina is describing not a musical instrument, but a simple water-mechanism which could form

Hero of Alexandria (many times); also a favourite of the Cappadocians. Texts searched using the Thesaurus Linguae Graecae on-line (http://www.tlg.uci.edu/).

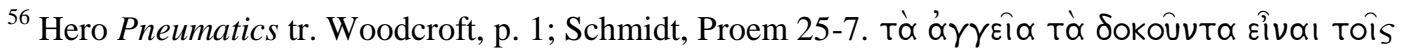

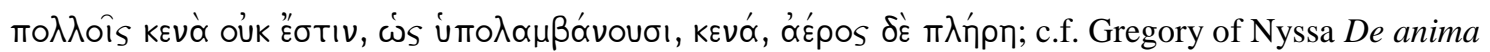

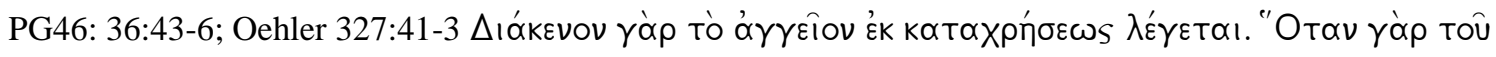

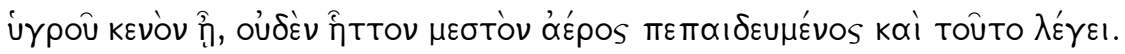

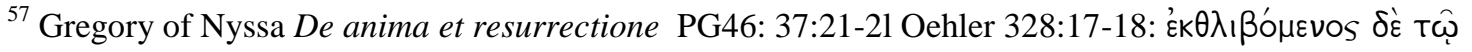

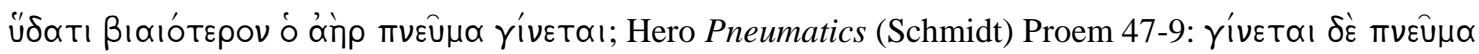

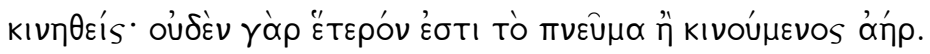


part of an automaton. I would hazard a guess that Gregory had either read Hero himself, or had read texts based closely on Hero's work. As with description of the phases of the moon, what Macrina describes is not based on very complex science or even on a very complex mechanism. It does reveal Gregory of Nyssa's knowledge of basic scientific principles, and of the fact that he held to some basic scientificphilosophical principles such as the denial of the existence of a void (which is, of course, famously discussed by Aristotle and others). ${ }^{58}$

But what is the aim of the example in the context of the dialogue as a whole? The point of it is to show that humans have rational souls. Its main object is not to present the automaton as an example of something material which is moved by something immaterial; this is because the common understanding of air as an invisible but quasi-material something (rather than nothing), would play into the hands of those (notably Stoics) who claimed that the soul was a material, albeit a superior material element, pervading the body. Instead, Gregory has Macrina argue that the existence of such automata shows that humans have rational souls because such machines could not have come into existence, as she says, 'automatically'.

Macrina's example, then, is a version of an argument from design - in this case not seeking to prove the existence of God from the presence of order in the universe, but rather seeking to show the existence of the immaterial human rational soul from the design of an automaton. The whole section on the automaton implicitly harks back to Macrina's complaints about Epicurus and his like who failed to recognise such a connection between design and a maker:

While the sight of a garment suggests to any one the weaver of it, and the thought of the shipwright comes at the sight of the ship, and the hand of the builder is brought to the mind of him who sees the building, these little souls gaze upon the world, but their eyes are blind to Him whom all this that we see around us makes manifest. ${ }^{59}$

\footnotetext{
${ }^{58}$ Aristotle, Physics Book VI especially parts 6-9.

${ }^{59}$ PG46: 24:4-10; Oehler 322:29-33; tr.NPNF V, p. 432
} 
The description of the automaton and the machine which makes a sound are, therefore, not primarily analogies about the invisible driving the visible. ${ }^{60}$ They argue that one can reason from observation of the construction of these objects to the existence of an human rational and immaterial soul. They remind the reader that humans are created in God's image, not only in the sense of their rationality, but in their ability to create - albeit at a far more basic level. However, the example of the automaton places in the reader's mind a disanalogy: humans can create human models which are purely material and which can only do what their human designers decide in advance; on the other hand, God can create humans endowed with rational, immaterial souls, who can act freely and of their own accord. Again, this recalls a comment Macrina made earlier in the treatise about Epicurus:

The nature of things was to his mind a fortuitous and mechanical affair

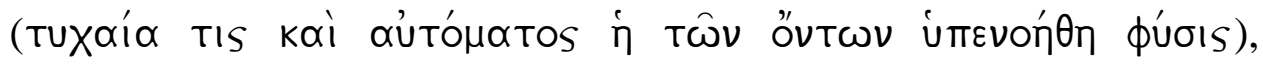
without a Providence penetrating its operations; and, as a piece with this, he thought that human life was like a bubble, existing only as long as the breath (Tò $\pi v \varepsilon \hat{U} \mu \alpha$ ) within was held in by the enveloping substance, inasmuch as our body was a mere membrane, as it were, encompassing a breath; and that on the collapse of the inflation the imprisoned essence was extinguished. ${ }^{61}$

\footnotetext{
${ }^{60}$ Nevertheless, that idea does perhaps lurk in our minds, and one cannot help speculating that Gregory intended it to do so. Given his philosophical context, it is perhaps not improbable that he intended the automaton to remain in his readers' minds as a visible analogy of the human as microcosms - a being

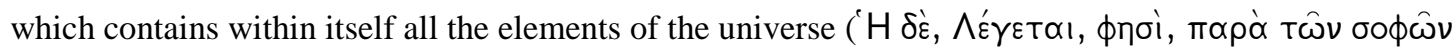

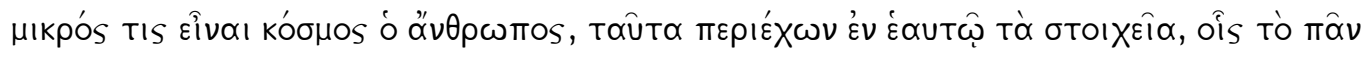

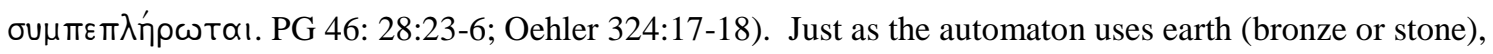
air, water and often fire (to heat the air or water to make it expand), so the human being, as the dialogue will go on to show, is composed of the four elements, earth, air, water and fire: see for example, the account of death and resurrection in terms of the dissolution and recombination of material elements ( $T \dot{\alpha}$ бтохХદi $\alpha)$ of different kinds, light, heavy, hot and cold: NPNF V, p. 437-8 (PG46: 44:24 - 48:40; Oehler, 330:30 - 332:25) and NPNF V, pp. 445 (PG46: 73:17 - 76:21; Oehler, 342:35 - 343:31).

${ }^{61}$ NPNF V, p. 432; PG46: 21:17-25; Oehler 322:13-18
} 
Epicurus' concept of human nature sounds very much like Macrina's description of the automaton - a material container encompassing material breath. In this context, therefore, Epicurus' mistake is revealed to be not only ignoring the argument from design, but also impiously reducing God's creation to the level of something that even humans could create.

However, the section of the dialogue which deals with the automaton also reemphasises what had been established by the astronomical examples: that knowledge requires the cooperation of both reason and the senses. In order to do this the

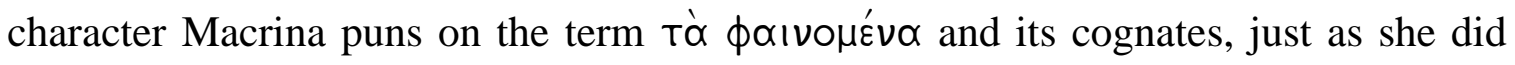
earlier:

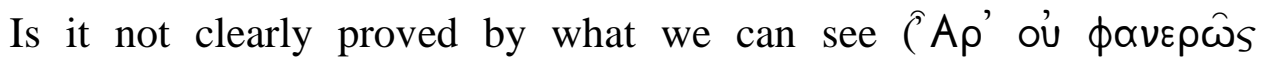

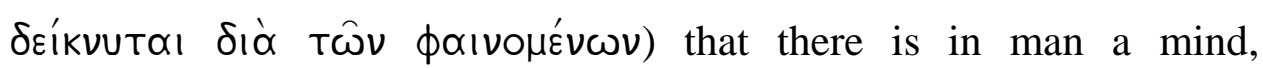

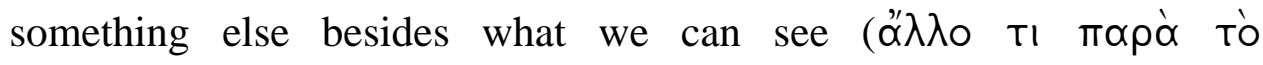

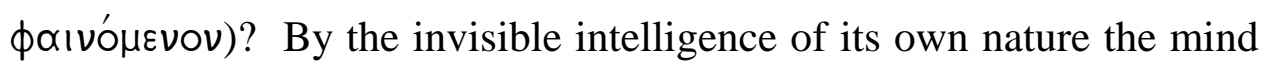
makes such plans by thought within itself; then as we have described, through material assistance it brings into the open the concept that exists within. ${ }^{62}$

In this way Gregory stresses that correct ideas come about through the observation of

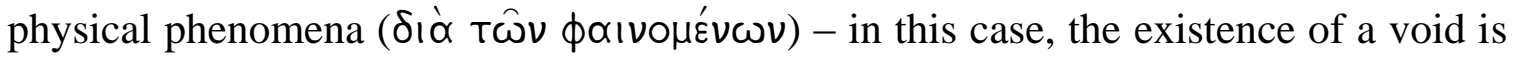
disproved by the close observation of the material reactions of air and water in a hollow container. ${ }^{63}$ The vivid language which is used to describe the action of water and air in the neck of the container emphasises the senses used: in Gregory's descriptions one hears the gurgle/plash of the water, one sees and feels the water foam. ${ }^{64}$ Furthermore, in both cases correct knowledge depends on the observation of movement: the cycles of the heavenly bodies and the movement of the automaton (including the movement of water and air which creates sound - which itself is

\footnotetext{
${ }^{62}$ Roth, p. 42; PG46: 37:29-32; Oehler 328:20-3

${ }^{63}$ PG46: 37:31; Oehler 328:22.

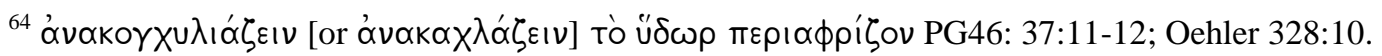


considered as a movement). For Gregory, movement is an archetypal quality of creation, both material and immaterial.

In sum, while Gregory's examples from astronomy establish the idea that one

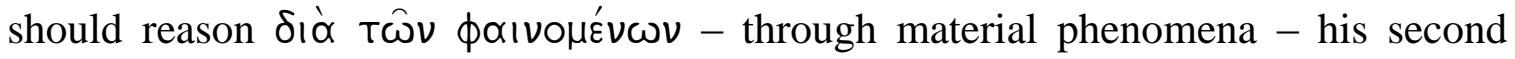
example of the automaton and its component parts, both reinforces this epistemological principle and applies it to a specific enquiry: the question of whether the soul exists.

\section{Conclusion.}

Gregory was not a scientist, in either the modern or the ancient sense. He reports fairly basic phenomena and gives fairly basic explanations. His descriptions are more complex than those found in most contemporary Christian theological treatises, but that is not a very high standard! He is most interested in the philosophical-theological principles underlying the scientific phenomena. However, these scientific examples should not be viewed merely as somewhat long-winded ways to make a fundamental philosophical point: rather, the way in which Gregory describes the phenomenon should be attended to. On one level, his descriptions reveal his characteristic wide-eyed wonder at the complexity of the world and its objects, both natural and man-made - a feature which can also be seen, for example, in his discussion of tears, laughter and dreams in the De hominis opificio, of the rainbow in Letter 38 (formerly attributed to Basil), of a garden in his letter to Adelphius. ${ }^{65}$ On a more profound level, the language and style of the descriptions, the way in which they highlight and echo themes present elsewhere in the dialogue, the way they employ the sophisticated interplay of analogy and disanalogy: all these literary techniques remind us that although Gregory was no man of science, he was a consummate man of letters.

With regard to the example from astronomy, it is striking that Gregory's comments on good philosophical method - that the immaterial intellect should work

\footnotetext{
${ }^{65}$ De hominis opificio §§12-13; [Basil] Letter 38; Gregory of Nyssa Letter 20 to Adelphius.
} 
through the material senses; that neither mind nor body sufficient on its own to understand the world - support the main theological thrust of the thesis: that humans are inextricably both material and immaterial. ${ }^{66}$ An emphasis on the positive nature of materiality is of course particularly important in this work which counters a Platonic belief in the immortality of the soul (as exemplified, for example, in the Phaedo), with a robustly material doctrine of the resurrection of the body. At a basic level the examples about the sun and moon establish the basic fact that one can reason about difficult things using a mixture of mind and senses. In addition, through using astronomical examples, Gregory highlights the importance of the senses - somewhat unexpectedly, perhaps, given that he began with the counter-example of Epicurus who wrongly only used sense experience. This section thus moves from the rejection of materialism, to an emphasis on the crucial role of reason, to the affirmation of the value of reason (the immaterial) and senses (the material) working together.

This method is similar to that lying behind the example of the automaton: Gregory presents (in his own voice) the sceptical materialist position that perhaps humans are just like automata driven by a material invisible breath; this is countered by Macrina who uses the example of automata to construct an argument from design concluding that mind must be present in human beings if they are capable of constructing such objects. Human might appear to be all matter (just as the sun might appear very small); reason however argues for the existence of a soul (just as it argues for the sun's huge size). However, in order to reach such a conclusion reason must work through the careful observation of a material phenomenon: the existence of the automaton (just as it must reason from the careful observation of the sun's movements). In order to emphasise this point that the mind works through materiality Macrina not only argues that one reasons through the observation of machines such as automata to conclude that the human soul exists, but she also emphasises the point that the human mind solved the problem of the vacuum by the close observation of the battle of water and air in the neck of a jar. (A more subtle, but no less telling

\footnotetext{
${ }^{66}$ They are also consonant with Gregory’s views elsewhere, see e.g. De hominis opificio $\$ 10$
} 


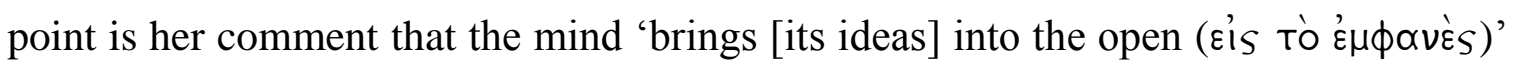

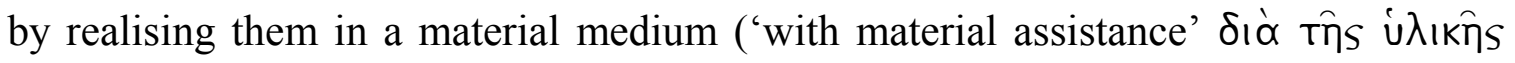

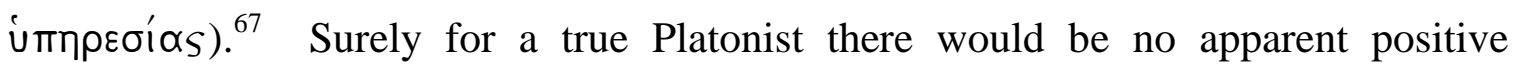
evaluation of the realisation of ideas in the material realm - quite the opposite.)

Thus the astronomy establishes a general epistemological point - that one should reason through the careful observation of material things - which is applied to the particular case of the soul in the automaton example. These examples are thus hardly mere decoration, intended to impress the reader of the dialogue with Gregory's scientific knowledge and large vocabulary : they move the argument of the dialogue along in a constructive way.

Furthermore, as we have seen, they exemplify a creative movement from materialist scepticism, to an emphasis on the immaterial mind/soul, to a reaffirmation of the importance of the senses/the material along with the immaterial soul - a movement which is exemplified in the structure of the dialogue as a whole. Thus Gregory begins by presenting (in his own grief-struck voice) the sceptical view: what if death is the end of everything? This is followed by an emphasis on the immortality of the soul, but again this is followed by the doctrine of the resurrection which stresses the restoration of human nature in its psychosomatic entirety. Furthermore, this dynamic can also be found in the way in which the dialogue surprises the reader by gradually working towards a more positive role for the emotions (commonly associated with the material in late antique thought), despite the fact that Gregory's grief and anger were portrayed in a very negative light at the beginning of the work. ${ }^{68}$ Macrina first seems to assume that emotions are material passions which must always be kept under control by reason, but by the end of the dialogue this view is tempered

\footnotetext{
${ }^{67}$ PG46: 37:31-2; Oehler 328:22

${ }^{68}$ Rowan Williams, 'Macrina's death-bed re-visited'; see also Warren Smith, J., 'A just and reasonable grief: the death and function of a holy woman in Gregory of Nyssa's Life of Macrina', in Journal of Early Christian Studies, 12:1 (2004), pp. 57-84 and Warren Smith, J., 'Macrina tamer of horses and healer of souls: grief and the therapy of hope in Gregory of Nyssa's De anima et resurrectione', Journal of Theological Studies, NS 54:2, (October 2000), pp. 37-60.
} 
by the idea that love (and on occasion even anger) are required to impel the believer towards God. At both levels, then - epistemological and theological - Gregory appears to start with a sceptical or materialist position, counters it with an emphasis on the immaterial, then corrects that with his Christian solution: one which asserts the reality of the immaterial, whilst acknowledging the goodness of God's material creation. The examples based on astronomy and automata fit in with, and indeed strengthen, this development which runs throughout the dialogue - they are in a sense a microcosm of the dialogue as a whole.

To a large extent, this treatise represents Gregory's Christian reaction to historical and contemporary Platonism. However, it should also be noted that in Plato's dialogues themselves there is an ambivalence towards the material especially towards the emotions - rather than an outright hostility. Famously, the Symposium and the Phaedrus are much more positive about the role of human love, for example. To this extent, then, the dialogue in the De anima et resurrectione is not just a dialogue between Christianity and Platonism, but it is a dialogue inserted into an on-going conversation within Platonism between different strands of Plato's own thought. (The way in which Macrina's character shifts between Socrates and Diotima, and her use of the motif of the soul's chariot from the Phaedrus alerts us to this subtlety.)

In this context, Gregory's examples from science are not just interesting in their own right (although they do yield interesting insights into what kinds of scientific text some fourth-century Greek-speaking fathers might have been reading). They are much more interesting for what they reveal about his skill as a writer and the subtlety of his thought. In De anima et resurrectione at least, Gregory is not simply showing off his rhetorical skill by using complicated scientific analogies which had only a limited application to his case in point but which gave him the excuse to use flashy vocabulary. Nor is he getting carried away with long-winded descriptions as if he were not fully in control of his own writing. The detail and the vocabulary are important - as I have tried to show here - because the expression and detail of the analogies themselves helps to push forward the argument in the dialogue. Firstly, 
they have a function in establishing an appropriate epistemology to be followed in the rest of the dialogue: the examples from astronomy show that knowledge is achieved through reason and observation working together, then this general principle is applied to a specific example to argue from the existence of complex machines that there is a human soul. Secondly, the scientific analogies prepare the reader for the importance of the materiality body in the rest of the dialogue: the structure of the analogies and the structure of the dialogue itself are united in emphasising the importance of God's creation in both its immaterial and material aspects. Finally, one should add, there is also a sense in which Gregory dwells on the details of heavenly phenomena, physical processes and scientific observation because he - unlike many of his philosophical contemporaries - thought that they were really important in themselves as part of a good, ordered, material creation. His pausing on the details is not rhetorical indulgence: ultimately, Gregory's scientific analogies matter because, for him, matter matters. 